\title{
Perception of Ecosystem Services in Constituting Multi-Functional Landscapes in Slovakia
}

\author{
Peter Bezák ${ }^{1, *} \mathbb{C}$, Peter Mederly ${ }^{2} \mathbb{}$, Zita Izakovičová $^{3}$, Milena Moyzeová ${ }^{3}$ and \\ Magdaléna Bezáková ${ }^{1}$ \\ 1 Institute of Landscape Ecology of the Slovak Academy of Sciences, Branch Nitra, Akademická 2, \\ 94901 Nitra, Slovakia; magdalena.bezakova@savba.sk \\ 2 Department of Ecology and Environmental Sciences, Faculty of Natural Science, Constantine the \\ Philosopher University in Nitra, Tr. A. Hlinku 1, 94974 Nitra, Slovakia; pmederly@ukf.sk \\ 3 Institute of Landscape Ecology of the Slovak Academy of Sciences, P.O. Box 254, Štefánikova 3, \\ 81499 Bratislava, Slovakia; zita.izakovicova@savba.sk (Z.I.); milena.moyzeova@savba.sk (M.M.) \\ * Correspondence: peter.bezak@savba.sk
}

Received: 29 April 2020; Accepted: 9 June 2020; Published: 12 June 2020

\begin{abstract}
Landscape provides many services for human wellbeing through its mosaic of ecosystems. Although different landscape spatial structures limit some access to these services for local residents, their demand for landscape benefits creates a crucial component in landscape planning. Herein, we evaluate the ecosystem service supply from landscape structures in four different areas of Slovakia and we identify the public preferences for these services. This evaluation was assisted by expert-based ecosystem services (ES) matrix assessment and feedback from experts and key local stakeholders. The associated land cover assessment revealed that although forests are the most important for ES delivery, followed by extensive agricultural mosaics, cultural services have the highest average supply value. In contrast, the experts and local stakeholders considered that provisioning services were the most important of all ES groups because of products available from arable land. The overall public awareness of benefits provided by nature proved relatively high, and this is a good sign for the development of multi-functional landscapes. The comparison of study sites revealed that even stakeholders living in intensively used land, with its overall low ES supply, assessed ES as very important in general. The general public could therefore be included in environmental planning to promote a more multi-functional landscape. In addition, the analysis herein will communicate gained insights to the local planners and decision-makers and confirm the importance of this ES participatory approach using top-down methodology. This may require the following measures in Slovakia: establishing an interdisciplinary group of experts for regular assessment of strategic landscape planning documents and regulatory instruments, developing key directives which establish well-balanced participatory procedures, improving open local government, and supporting down-scaled implementation of integrated landscape planning in cooperation with local action groups.
\end{abstract}

Keywords: ecosystem services; land cover; stakeholders; planning

\section{Introduction}

Landscape as an object is variously perceived and defined, but most definitions present it as a spatial complex unit with internal interactions or as a dynamic socio-ecological system. While Forman and Godron [1] portray the landscape as a heterogeneous part of the earth's surface with mutually interacting ecosystems, the Millennium Ecosystem Assessment (MEA) defines the landscape as an area of land that contains a mosaic of ecosystems, including human-dominated ecosystems [2]. 
These mosaics include forests, agricultural land, wetlands, and human settlements and their spatial interaction considerably determines the landscape characteristics.

There are many methods of assessing landscape characteristics and its supply of benefits for human wellbeing, and most assessments include the following wide spectrum of scientific approaches: measures of naturalness, the hemeroby concept [3], landscape function assessment [4,5], landscape metrics [6,7], and participatory planning tools [8-10].

Landscape provides goods and services to human wellbeing through the mentioned ecosystems. Linkage of the natural ecosystems to the benefits and values of the community living in the landscape can be expressed by the concept of ecosystem services [11]. The ecosystem services (ES) in the Millennium Ecosystem Assessment are the benefits people obtain from ecosystems and these include provisioning, regulating, supporting, and cultural services [2]. The latest and more developed classification of ecosystem services-Common International Classification of Ecosystem Services (CICES) [12]-merges regulating and supporting services to the "regulation and maintenance" category. The CICES classification is used by MAES (Mapping and Assessment of Ecosystem Service), an analytical framework for wide ES assessment applied by the European Union (EU) and its Member States [13].

Iverson et al. [14] stressed that most ES are location-based and that an integrative landscape approach is the best method of assessing them. In addition, ES study at the landscape level usually includes evaluating land use and land cover types [15-17] and also social perception of ES/landscape [18,19]. These are then augmented by participatory approaches, which include establishing social preferences through a public rating system [19] and combining this with expert knowledge of the potential capacity of individual ecosystems to deliver services and goods [16,20].

However, landscape configurations and other socio-economic factors may determine uneven spatial distribution of ES supply and inequalities in the possibility of access to people. To account for this, Paracchini et al. [21], for example, presented a framework to assess EU potential for outdoor recreation as a cultural ES physically accessible to local people. In addition, other citizens had their own social preferences for using a particular ecosystem service [11,19]. Although several studies have analyzed ES supply and demand aspects [17,22], the research into these aspects' direct correlation is underdeveloped, and this includes important investigation into social demand. Garcia-Nieto [23], however, provided an exception by linking forest ecosystem capacity with delivery of an ES service which satisfied social demand at the local scale.

The underdeveloped supply and demand issue inspired this paper to focus on the assessment of services provided by particular ecosystems on the landscape scale, especially their public perception. This then reflects local socio-ecological systems in the assessment of land use patterns. Our study refers to "ecosystem services at the landscape level" because this expression links ecological knowledge and collaborative landscape planning. These are also associated with pattern-process relationships and are therefore more legitimate and relevant to local practitioners [24]. The services are related to landscape elements such as buildings and other anthropogenic structures and not necessarily to natural capital [25], and these landscape-oriented services focus more on the interplay between humans and the environment in land use [25]. Here, the European Landscape Convention [26] landscape definition is also beneficial. The Convention defines landscape as "an area, as perceived by people, whose character is the result of the action and interaction of natural and/or human factors."

In addition, the increasing social demand to improve quality of life can support linking the concept of ES with other planning strategies and practices ranging from the global to local scale. It may include, for example at EU level, water and climate policy directives, regulations for urban/rural areas [27], or social and economic development programs in local planning [28]. The ES concept can also contribute to human health issues that still seem to be a challenge in the planning process $[29,30]$.

Access to ecosystem services depends on the characteristics of the landscape and the crucial spatial configuration of its components. Landscapes with a significant degree of natural capital resources tend to provide better balanced provision of ecosystem services. Therefore, landscape with high capacity to provide socio-economic and ecologic benefits to society is considered multi-functional [31,32]. 
This includes the potential trade-offs and synergies between individual ecosystem functions and services. Different landscape structures at the selected Slovak sites enable assumption of the varying potential of ecological and socio-economic benefits for the community. This inspired the formulation of our main research question: How do people engaged in local landscape planning perceive the importance of the services generated in it? We resolved this question by employing simple ecosystem services mapping and feedback from expert opinion and key local stakeholders to evaluate the current land use structure in four different Slovak landscapes. Here, we linked the selected services supply and the related local stakeholders' preferences. The results of this analysis communicate insights to local planners and decision-makers, and they clarify the importance of expert and local community perception of the ecosystem services' potential to constitute a multi-functional landscape.

\section{Materials and Methods}

\subsection{The Study Areas}

Available information enabled the selection of four study areas in Slovakia for this research. It was important that they differed in landscape structures and in the spatial extent of their natural and semi-natural ecosystems. These study areas are also specific because of their different cultural histories and socio-economic capital. Moreover, the socio-ecological variation in the study areas ensures different ecosystem service capacities and diverse traditions in their use. Table 1 herein lists the total areas, the number of inhabitants, location of study areas, and the main landscape structures. Figures 1 and 2 then provide the geographical position and the main land cover classes.

The Suchá nad Parnou-Zvončín area is referred to as Suchá nad Parnou throughout the text, and this district is dominated by intensive agriculture. It is located in the southern lowland areas with the most fertile soils and favorable climatic conditions, and the remaining Raková, Hriňová, and Liptovská Teplička study areas are in mountainous and sub-mountain landscapes where forestry and mountain farming predominate, as shown in Figure 2. The majority of the Hriňová and Liptovská Teplička areas are Natura 2000 sites.

Table 1. The total area, number of inhabitants, and the location and landscape structural character of all study areas.

\begin{tabular}{|c|c|c|c|c|c|}
\hline No. & $\begin{array}{c}\text { Study Area } \\
\text { (Municipality) }\end{array}$ & $\begin{array}{c}\text { Total Area } \\
\text { (ha) }\end{array}$ & $\begin{array}{l}\text { Population } \\
\text { (in 2019) }\end{array}$ & $\begin{array}{c}\text { Location } \\
\text { (Middle Point) }\end{array}$ & Short Landscape Description \\
\hline 1 & $\begin{array}{l}\text { Suchá nad } \\
\text { Parnou-Zvončín }\end{array}$ & 2262 & 2957 & $\begin{array}{l}48^{\circ} 24^{\prime} 40^{\prime \prime} \mathrm{N} \\
17^{\circ} 29^{\prime} 22^{\prime \prime} \mathrm{E}\end{array}$ & $\begin{array}{l}\text { Intensive agricultural landscape with } \\
\text { compact village, dominance of large } \\
\text { arable fields, remnants of deciduous } \\
\text { forest, partly mosaic vineyards, gardens, } \\
\text { and grasslands. }\end{array}$ \\
\hline 2 & Raková & 4150 & 5581 & $\begin{array}{l}49^{\circ} 27^{\prime} 33^{\prime \prime} \mathrm{N} \\
18^{\circ} 43^{\prime} 10^{\prime \prime} \mathrm{E}\end{array}$ & $\begin{array}{l}\text { Intra-mountain basin landscape with } \\
\text { compact village and large adjacent } \\
\text { grasslands, surrounded by mountain } \\
\text { slopes with dispersed settlements and } \\
\text { mosaic of coniferous forest and extensive } \\
\text { agricultural plots. }\end{array}$ \\
\hline 3 & Hriňová & 12,644 & 7435 & $\begin{array}{l}48^{\circ} 36^{\prime} 15^{\prime \prime} \mathrm{N} \\
19^{\circ} 31^{\prime} 20^{\prime \prime} \mathrm{E}\end{array}$ & $\begin{array}{l}\text { Sub-mountain and mountain mixed } \\
\text { agricultural-forestry landscape with } \\
\text { dispersed settlement, small parcels of } \\
\text { agricultural land, coniferous and mixed } \\
\text { forest in upper part of territory. }\end{array}$ \\
\hline 4 & $\begin{array}{l}\text { Liptovská } \\
\text { Teplička }\end{array}$ & 9869 & 2412 & $\begin{array}{l}48^{\circ} 57^{\prime} 52^{\prime \prime} \mathrm{N} \\
20^{\circ} 04^{\prime} 26^{\prime \prime} \mathrm{E}\end{array}$ & $\begin{array}{l}\text { Mountain landscape with extensive } \\
\text { pastures and valley meadows on steep } \\
\text { slopes adjacent to compact village, } \\
\text { coniferous forest some distance away. }\end{array}$ \\
\hline
\end{tabular}




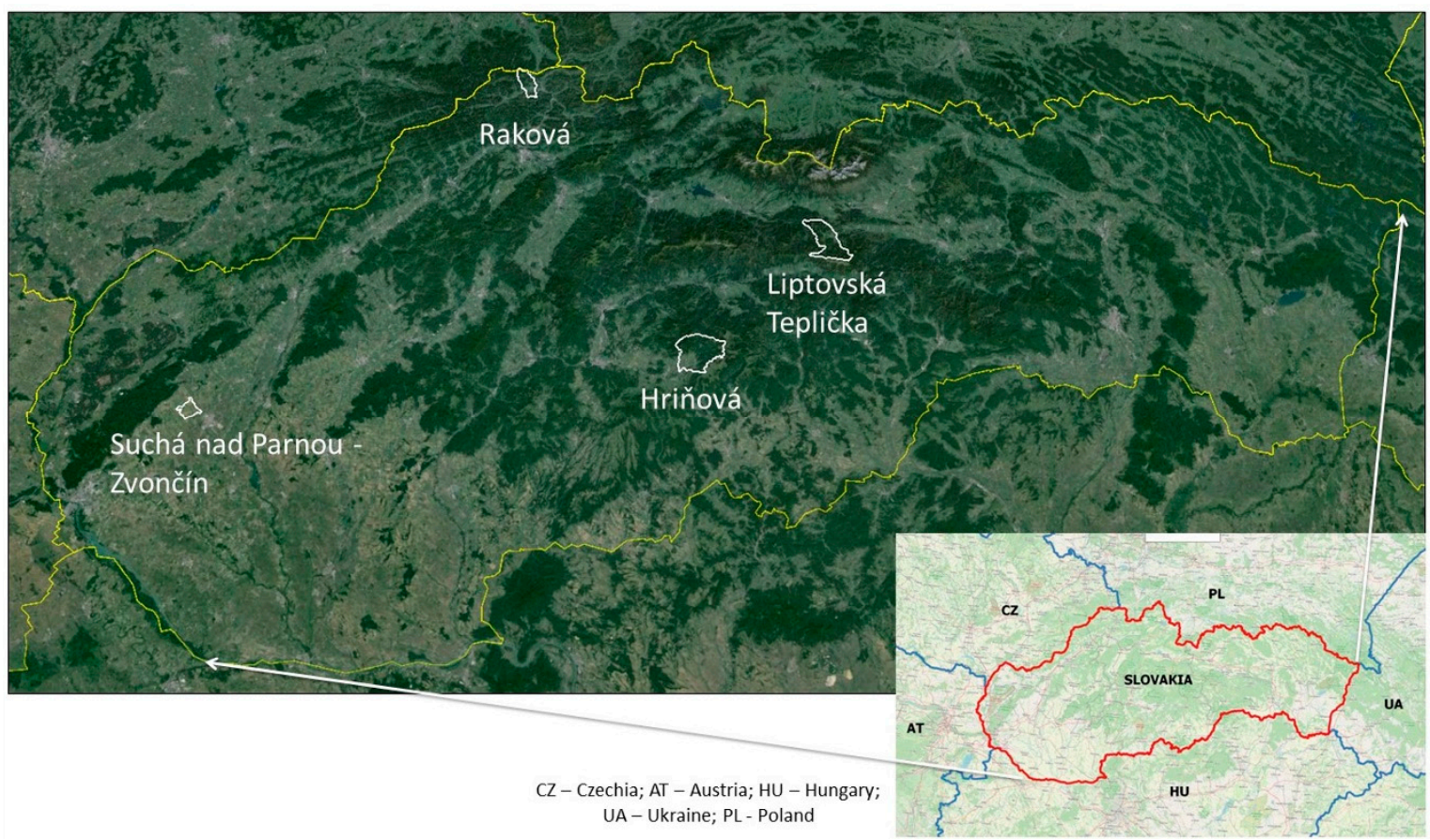

Figure 1. Geographical position of the selected study areas in Slovakia.

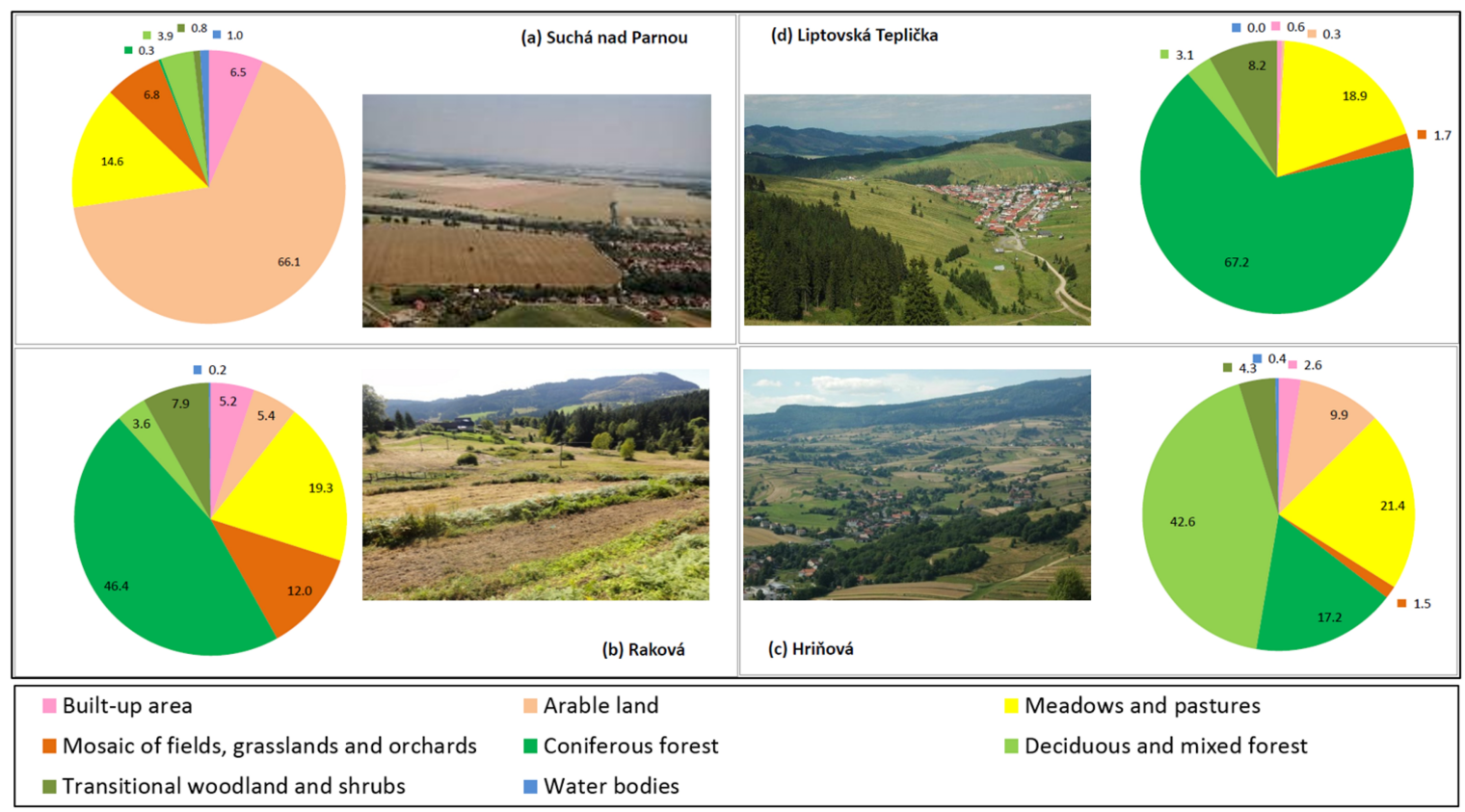

Note: Values around the perimeter are in the same order as items in the legend

Figure 2. Land cover in the four selected study areas (in \%). (a) Suchá nad Parnou, (b) Raková, (c) Hriňová, (d) LiptovskáTeplička.

\subsection{Research Concept and Basic Analytical Data}

The concept of ES classification in the MEA [2] formed the baseline for our research. The following four categories were considered: (1) provisioning services, (2) regulating services, (3) supporting services, and (4) cultural services. The research team experience enabled selection of individual services from each category most relevant for the case studies and easily understandable for the stakeholders. This knowledge comes from implemented projects focused on the ES assessment, e.g., the OpenNESS project [33], with significant engagement of the experts, key stakeholders, and public. Based on the 
previous participatory approaches' experience on preference and assessment of ES, we then selected the following: (1) the three supporting services of biodiversity, nutrient loss reduction, and storage capacity; (2) the provisioning services of crops, fodder, timber, and freshwater; (3) the regulating services of local climate, flood, air quality, water quality, erosion, and pollination; and (4) the grouped cultural services of aesthetics and recreation, as shown in Figure 3. This provided an assessment of 14 ecosystem services and it is highly likely that such a great number of services would give better ES insight and ensure greater landscape multi-functionality [32].

The basic CORINE land cover (CLC) data relevant for Slovakia were then assessed within a questionnaire survey in Section 2.3 below to obtain the perceptions of landscape structure to provide ES held by experts and local stakeholders $[34,35]$. Although a limitation of this method is not to account for land use intensity, which is an important aspect of ES evaluation [36-38], but the CLC classification proved to be straightforward to capture the main elements in the study area and is sufficiently simple to evaluate the potential capacity to provide ES for human wellbeing by stakeholders [16,17]. While the matrix and the questionnaire identified 15 basic CLC types relevant to the model areas, as shown in Figure 3, a more detailed land cover spatial resolution expressed the map results described in Section 2.4 below.

\subsection{Questionnaire Survey}

The questionnaire survey provided additional input to assess the ecosystem services supply potential in each case study area and it also outlined the demand and local preferences for their use. The ES supply methodology is derived from the expert-based ES capacity matrix in Burkhard et al. [16] and this is widely applied and tested [20,39-41]. The expert-based matrix allows rapid implementation and it delivers ES evaluation results approximated by those obtained by biophysical models at the level required for assessment of multiple ES [40,42]. Furthermore, the main focus of our research was put on the perception of the relative importance of different ES by stakeholders, for which the matrix method we considered as sufficient.

The survey was performed by the research team and conducted with 18 experts in ES research from Slovakia and with 5-10 key stakeholders in each study area. The experts were recruited from universities, scientific institutes, non-governmental organizations (NGOs), and relevant organizations. The stakeholders included municipal mayors and their representatives, representatives of co-operative farming organizations and other key farmers, representatives of state forest authorities and nature conservation bodies, and other key land users.

The questionnaire template contained personal information, including respondent age, gender, classification of economic activity, occupation, and the following important ES questions:

(1) Which ES from those listed below are the most important in your opinion? The relative importance was given to provisioning, regulating, supporting, and cultural ES in the provision of human wellbeing benefits. The questionnaire scale ranged from 0 for no importance to 5 for extremely important. We further calculated the mean values of all responses and a weighted coefficient for computing the overall capacity of each CLC type for ES provision required in Question 2. The weighted coefficient was calculated for each study area based on local preferences of ES categories.

(2) What is a capacity of the below listed landscape elements to provide benefits for human wellbeing (ES)? In this question, the capacity of different CLC types to provide ES was identified. This question was slightly different for the experts and the stakeholders. A general matrix was created for the experts to judge the Slovak geographical capacity of the 15 CLC types to provide 14 selected individual services, as shown in Figure 3. The matrix for each case study included site-specific CLC types, and the stakeholders evaluated these in the four ES categories. The scale for both target groups was again zero to 5 for the same purpose as in the previous question. The mean value again summarized responses at each matrix cell. The interpretation of these results was processed by the mean values for a particular service and CLC type (0-5) or the sum of these values (the second last row in Figure 3) and with \% applied for ES category or the 
overall ES provision (the last column in Figure 3). The average relative value for each ES category group per CLC type is expressed as a percentage of the maximum value that could be potentially achieved. For example, natural grassland achieved $83.9 \%$ for supporting ES from the mean values of $4.8,4.0$, and 3.8 assigned for the related particular ES, while the maximum of $100 \%$ would be achieved if 5.0 is the value in each of these matrix cells. Overall average value per ES category for all CLC types is expressed in the second last row of Figure 3. The overall ES provision capacity was interpreted as the sum of the average relative value for each ES category group per CLC type, while each average value was multiplied by the weighted coefficient from Question 1 and which is shown in the last row of Figure 3.

\subsection{Spatial Calculation}

We calculated the average capacity for each studied landscape and the overall Slovak republic capacity to give a quick overview of the differences in landscape potential to provide the four ecosystem services groups. Here we applied Vihervaara et al.'s formula [39]:

$$
\mathrm{C}_{\mathrm{ES}}=\sum \mathrm{CLC} \frac{\mathrm{X}_{\mathrm{avecapCLC}} \mathrm{A}_{\mathrm{CLC}}}{\mathrm{A}_{\text {total }}}
$$

where $\mathrm{C}_{\mathrm{ES}}$ is the average territorial/spatial capacity of the study region to provide $\mathrm{ES}, \mathrm{X}_{\text {avecapCLC }}$ is the average capacity of each CLC type to provide ES based on expert evaluation in Question 2, $\mathrm{A}_{\mathrm{CLC}}$ is the area of CLC type in the study region, and $A_{\text {total }}$ is the total area of the study region.

The results were aggregated to achieve ES capacity values for each service group, and further aggregated to gain the overall capacity value for each study area. CLC spatial resolution is insufficient for landscape planning and management, so the CLC class values were transformed into the detailed geographic information system database (GIS) for the map results, i.e., larger CLC polygons were split to smaller polygons based on more detailed datasets while keeping the CLC nomenclature. This was created in ArcMap 10.1 software by synthesis of thematic cartographic data obtained from the Geodesy, Cartography and Cadastre Authority of the Slovak Republic [43], especially useful for a built-up area, a detailed dataset on forests from the National Forest Centre of the Slovak Republic [44], and recent study-area aerial photographs (ArcMap layer). This is then applicable at the 1:25,000 to 1:50,000 local scale.

\section{Results}

\subsection{Ecosystem Services Capacity}

The results obtained from the expert assessment in Question 2, and highlighted in Figure 3, indicate the crucial importance of forests; especially mixed and deciduous forests. The forest land cover categories have the highest capacity to deliver a variety of goods and services for human wellbeing. The average overall value is $76-81 \%$ of maximum capacity of all ES categories (the last column in Figure 3). Forest benefits are apparent in each ES category, and they are ranked highly in almost all selected individual services, especially in regulating services. The extensively used transitional woodlands, natural grasslands, and complex cultivation patterns also have high capacity at $67-73 \%$. Meadows and pastures, agricultural land with natural vegetation, and water bodies deliver ES at $57-63 \%$ and their potential is important especially for cultural services and for the provision of crops, fodder, and some supporting and regulating services. The remaining CLC classes have under $38 \%$ capacity for the overall ES provision, and these recorded the lowest average values for all evaluated services. The exception was sport and leisure facilities for its recreation value $(76 \%$ achieved for cultural ES) and arable land which provides crops and fodder (50\% for provisioning ES). 


\begin{tabular}{|c|c|c|c|c|c|c|c|c|c|c|c|c|c|c|c|c|c|c|c|}
\hline CLC classes / Ecosystem services & 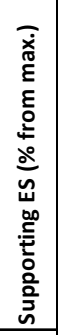 & 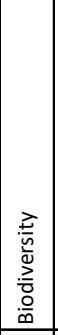 & 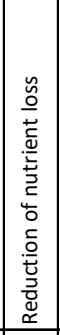 & 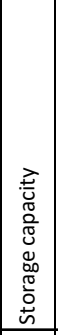 & 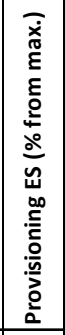 & 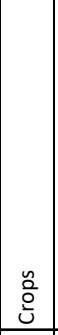 & $\begin{array}{l}\overline{0} \\
\frac{0}{0} \\
0 \\
\end{array}$ & 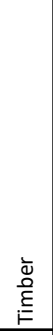 & 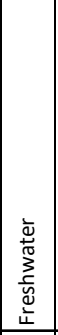 & 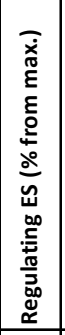 & 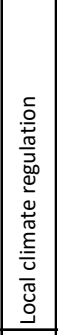 & 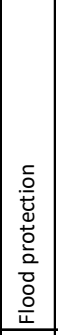 & 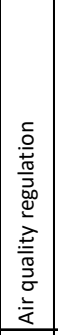 & 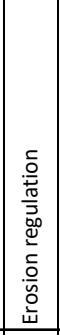 & 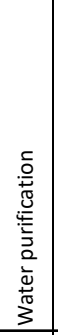 & 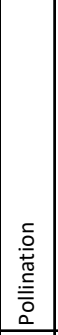 & 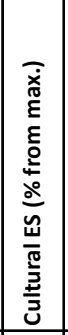 & 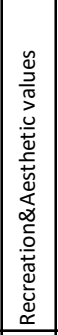 & 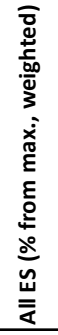 \\
\hline Discontinuous fabric & 31.4 & 2.1 & 1.4 & 1.3 & 23.2 & 1.6 & 1.0 & 0.8 & 1.2 & 31.8 & 1.6 & 1.9 & 1.1 & 2.1 & 1.5 & 1.4 & 55.0 & 2.8 & 34.0 \\
\hline Industrial or commercial units & 7.1 & 0.5 & 0.1 & 0.4 & 5.0 & 0.1 & 0.1 & 0.2 & 0.6 & 14.9 & 0.9 & 0.8 & 0.6 & 1.1 & 0.8 & 0.3 & 10.6 & 0.5 & 9.2 \\
\hline Roads and rail networks & 9.6 & 0.9 & 0.2 & 0.4 & 5.9 & 0.1 & 0.3 & 0.6 & 0.2 & 14.3 & 0.5 & 1.4 & 0.4 & 1.6 & 0.2 & 0.2 & 21.1 & 1.1 & 12.1 \\
\hline Construction sites & 5.9 & 0.5 & 0.2 & 0.2 & 4.4 & 0.2 & 0.0 & 0.1 & 0.6 & 8.3 & 0.4 & 0.6 & 0.3 & 0.8 & 0.4 & 0.1 & 4.7 & 0.2 & 5.9 \\
\hline Sport and leisure facilities & 22.2 & 1.2 & 1.1 & 1.1 & 8.8 & 0.2 & 0.5 & 0.5 & 0.5 & 24.7 & 1.6 & 1.1 & 1.1 & 1.4 & 1.1 & 1.1 & 76.1 & 3.8 & 29.9 \\
\hline Non-irrigated arable land & 39.6 & 1.7 & 2.0 & 2.2 & 49.7 & 4.5 & 4.2 & 0.1 & 1.1 & 27.9 & 1.6 & 1.6 & 1.1 & 1.3 & 1.5 & 1.4 & 30.0 & 1.5 & 37.6 \\
\hline Meadows and pastures & 70.9 & 3.8 & 3.5 & 3.4 & 52.2 & 2.9 & 4.8 & 0.4 & 2.3 & 64.2 & 3.0 & 3.3 & 2.6 & 3.6 & 2.9 & 3.8 & 67.8 & 3.4 & 63.4 \\
\hline Complex cultivation patterns & 73.9 & 4.1 & 3.5 & 3.4 & 59.9 & 4.1 & 4.2 & 1.3 & 2.3 & 65.8 & 3.2 & 3.4 & 2.8 & 3.5 & 3.0 & 3.9 & 81.7 & 4.1 & 69.5 \\
\hline Agriculture\&natural vegetation & 68.8 & 3.6 & 3.3 & 3.4 & 55.0 & 3.7 & 3.6 & 1.9 & 1.8 & 61.4 & 3.1 & 3.0 & 2.6 & 3.3 & 2.8 & 3.6 & 63.9 & 3.2 & 62.2 \\
\hline Broad-leaved forest & 87.5 & 4.4 & 4.4 & 4.4 & 54.1 & 1.4 & 0.9 & 4.9 & 3.5 & 86.3 & 4.7 & 4.7 & 4.4 & 4.7 & 4.2 & 3.2 & 88.3 & 4.4 & 78.1 \\
\hline Coniferous forest & 80.6 & 3.8 & 4.1 & 4.2 & 53.8 & 1.4 & 0.9 & 4.9 & 3.5 & 85.7 & 4.6 & 4.6 & 4.4 & 4.7 & 4.2 & 3.2 & 89.4 & 4.5 & 76.3 \\
\hline Mixed forest & 91.4 & 4.6 & 4.6 & 4.5 & 53.8 & 1.5 & 1.0 & 4.7 & 3.6 & 89.1 & 4.8 & 4.8 & 4.6 & 4.9 & 4.4 & 3.3 & 92.8 & 4.6 & 80.7 \\
\hline Natural grassland & 83.9 & 4.8 & 4.0 & 3.8 & 49.9 & 2.6 & 3.9 & 0.6 & 2.9 & 72.7 & 3.4 & 3.5 & 3.1 & 3.7 & 3.7 & 4.4 & 89.4 & 4.5 & 72.7 \\
\hline Transitional woodland shrub & 76.9 & 4.1 & 3.9 & 3.6 & 44.6 & 1.6 & 2.0 & 2.8 & 2.4 & 73.5 & 3.4 & 3.8 & 3.5 & 4.0 & 3.6 & 3.7 & 77.2 & 3.9 & 67.1 \\
\hline Water bodies & 67.3 & 3.8 & 3.0 & 3.3 & 33.1 & 1.4 & 0.5 & 0.2 & 4.4 & 49.8 & 4.3 & 3.6 & 2.2 & 0.8 & 3.4 & 0.6 & 86.5 & 4.3 & 57.2 \\
\hline Total for ES / Average for group of ES (\%/ & 54.5 & 43.8 & 39.2 & 39.6 & 36.9 & 27.4 & 28.1 & 24.2 & 31.0 & 51.4 & 40.8 & 42.0 & 35.0 & |41.6 & 37.7 & 34.1 & 62.3 & 46.7 & \\
\hline Weight of ES categories (question1) & 0.27 & & & & 0.28 & & & & & 0.26 & & & & & & & 0.20 & & 1.00 \\
\hline
\end{tabular}

Figure 3. Matrix of experts' judgment of land cover types across selected ecosystem services (the values 3.5 and higher per particular CORINE land cover (CLC) type and the service are highlighted in green, overall ecosystem services (ES) provision per CLC type above $60 \%$ is highlighted in orange, the average values, the sums and the weights are in bold and they are explained in Section 2.3).

The sum of the mean values per specific ecosystem service and all land use categories, expressed in the second last row of Figure 3, shows that the following services are perceived as most beneficial for human wellbeing: (1) the cultural services' aesthetic and recreational values achieving the score 46.7; (2) supporting services' biodiversity; and (3) the regulating services' erosion regulation, flood protection, and local climate regulation. Provisioning services had the lowest values, and freshwater was the best with the score of 31 .

The cultural services category had the highest (62.3\%) overall average ranking of all considered landscape elements. The experts concluded that the recent land use capacity was best for aesthetics and recreation. This was much better than the other ES categories, especially the provisioning services which rated only $36.9 \%$.

These results define the recent landscape capacity to provide ecosystem services for human wellbeing. Transformation of the expert results to land use in each case study area provided the local landscape capacity to deliver required services. Here, Figure 4 highlights the comparison of the overall territorial capacity for provision of ES categories and Figure 5 depicts the overall territorial capacity of all ES in the study areas. These graphs highlight the significant differences between the studied regions. The overall territorial capacity to deliver the studied services is generally low in Suchá nad Parnou at 1.94 to 2.44 for each ES category, because almost $70 \%$ of this territory is arable land and the experts give it a low ranking. The landscape provides medium (2.44) capacity for provisioning services. This is the only category close to other study area values, and the landscape's capacity to deliver other ecosystem services is far behind those areas. 


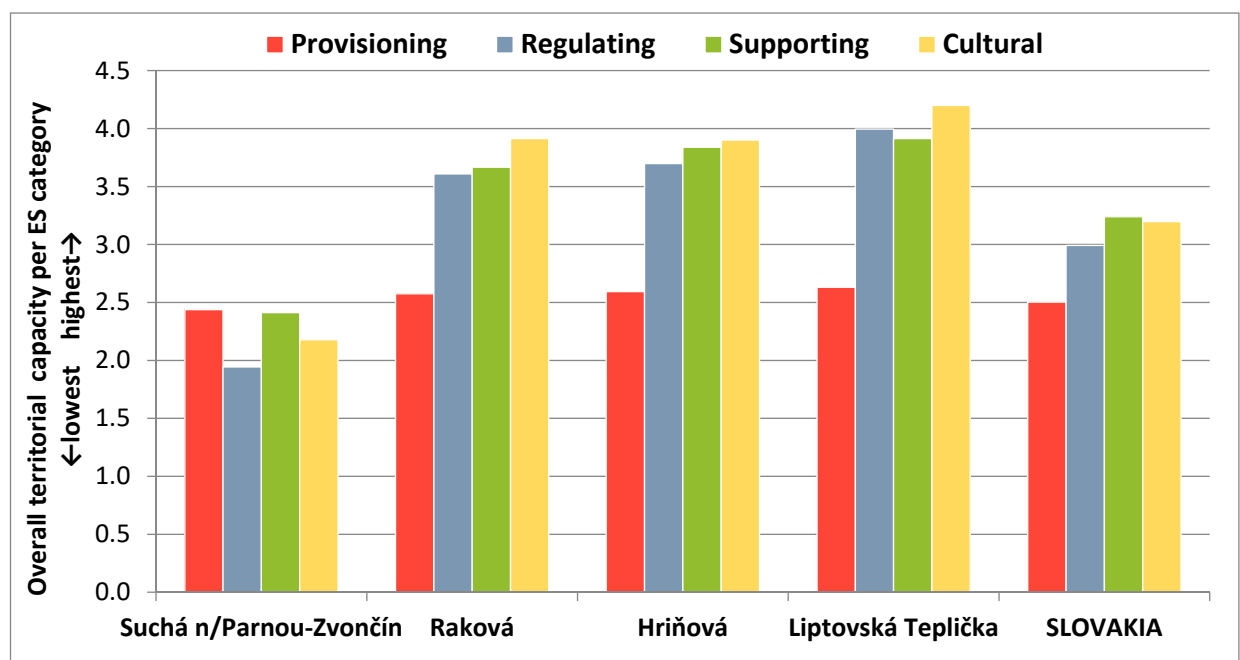

Figure 4. Overall territorial capacity per ES category based on experts' values.

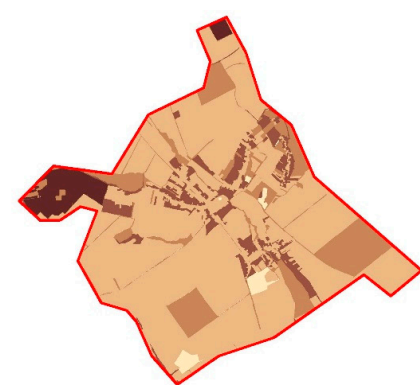

(a) Suchá nad Parnou - Zvončín

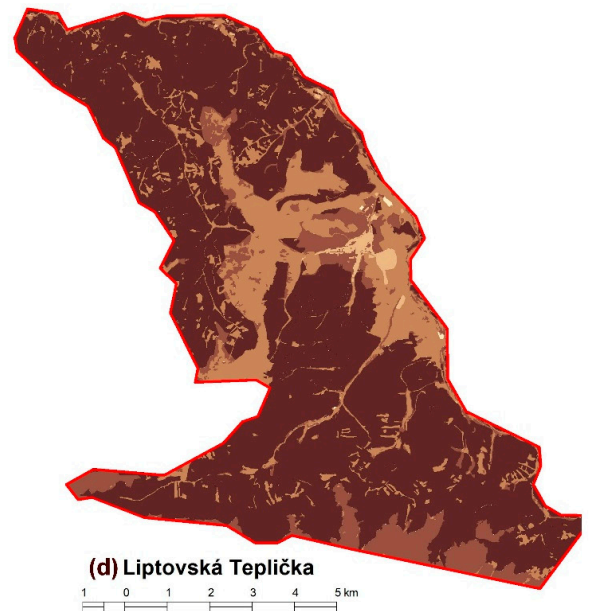

Overall ES capacity (\% of maximum capacity) very low $(5.9-12.1 \%)$

low (12.2-37.6\%)

average $(37.7-63.4 \%)$

high (63.5-72.7\%)

very high $(72.8-80.7 \%)$

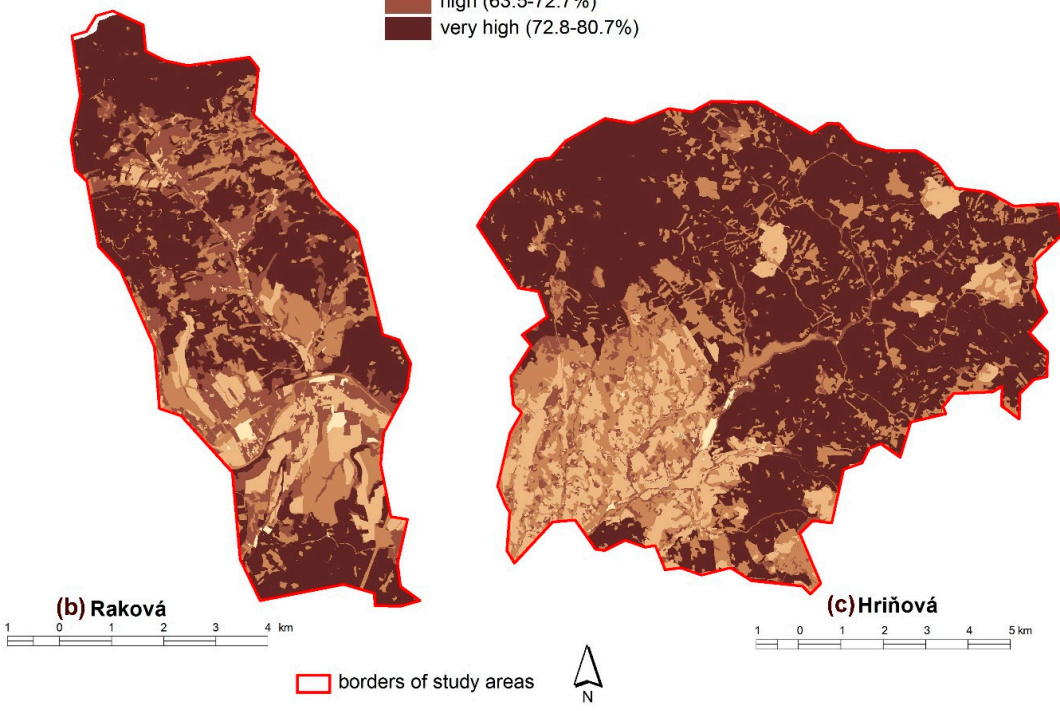

Figure 5. Overall territorial capacity for all ES based on values from experts' judgment. (a) Suchá nad Parnou, (b) Raková, (c) Hriňová, (d) LiptovskáTeplička. 
Comparison of the remaining Raková, Hriňová, and Liptovská Teplička experimental areas highlights no significant difference in the mountain regions despite varied land cover. The greater than $88 \%$ dominance of forest and extensively used areas provides an assumption of their high capacity for ecosystem services delivery. While provisioning services have only medium (2.58-2.63) capacity, all other ES categories here are positively perceived, with 3.61-4.2, and the Liptovská Teplička area has the highest capacity. Figure 4 highlights the high capacity of these three study areas to provide a variety of services. Their rating is generally superior to the national figures, and the Slovak national landscape capacity lies between the Suchá nad Parnou's capacity from its intensively used agricultural landscape and the capacities of the mountain and sub-mountain landscapes in the other three case studies.

\subsection{Social Preferences in Ecosystem Services Groups and Land Cover}

In response to the questionnaire's first question, the experts judged landscape provisioning services very important with the average value over 4.7 . This rating is a little higher than the 4.5 to 4.3 they assigned to the supporting and regulating services, and they considered cultural services less important at 3.4, as shown in Figure 6. Figure 6 also shows that the key local stakeholders rate similarly, i.e., provisioning services highly and the cultural services as least important. One exception to this trend was noted in the Hriňová rating, where there was only a slight difference in ES category importance. Here, the stakeholders considered regulating services very important, with a 4.5 rating, cultural services almost equally important at 4.1, and they valued both these ES groups more highly than the supporting services.

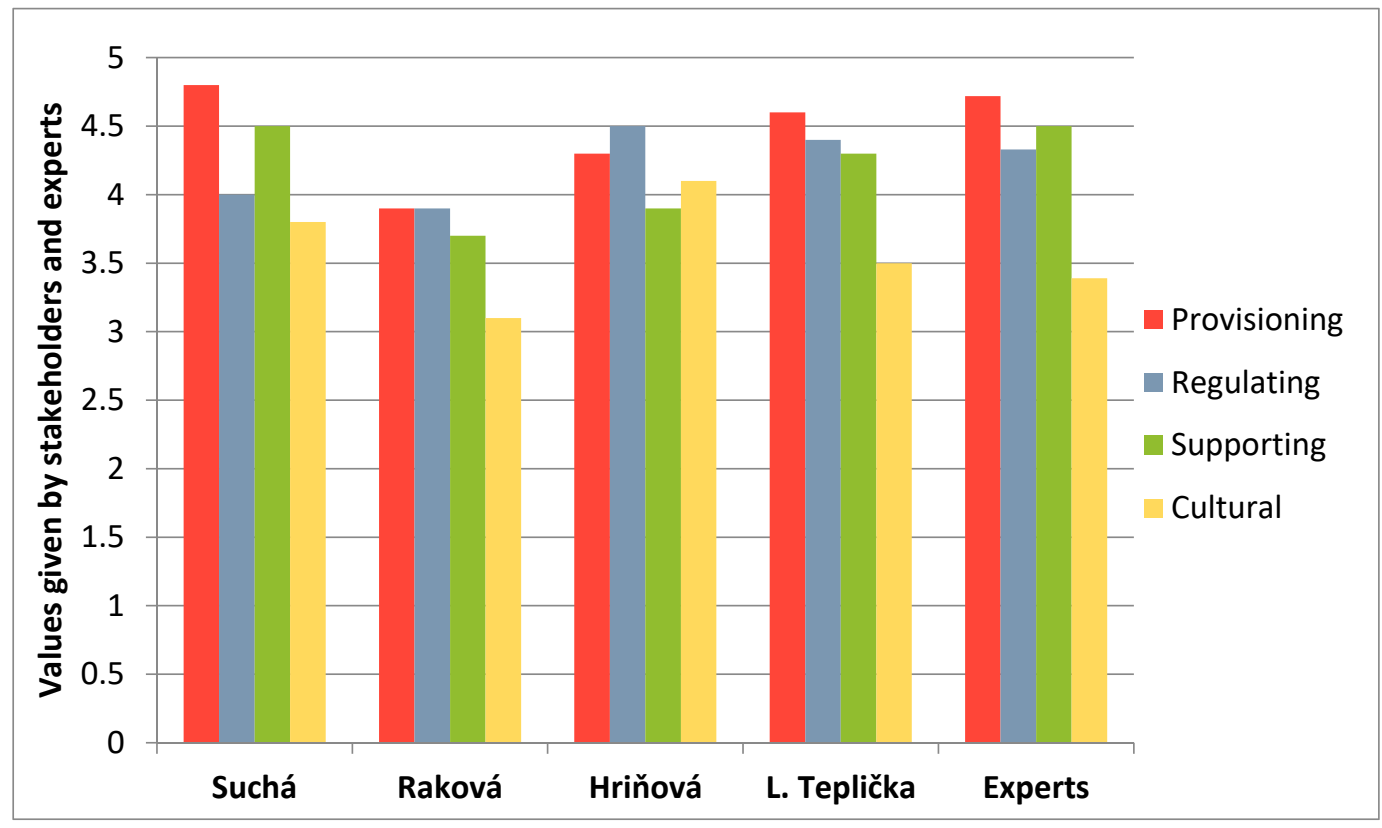

Figure 6. Importance given to ES categories by local stakeholders and experts.

The Question 2 responses to the importance of land cover types and their ability to provide human wellbeing services produced the results recorded in Figure 7. Although this figure shows only overall values for each land cover type in each study area, in the following sentences we summarize the main findings. Local stakeholders generally ranked the highest values of 3.7 to 4.25 to forest areas and specifically 4.4 for their provision of regulating services. This was closely followed by agricultural mosaics and water areas, which recorded a 4.2 value for cultural services especially. Arable land scored only from 2 to 3.5 as the lowest average values for all ES groups, however, it recorded 4.3 as the value for provisioning services because the stakeholders considered this the key landscape element in delivering related benefits. Their meaning here is that arable land is much less important in supplying regulating and cultural ES benefits, and they therefore gave this lack of importance the lowly ranked 
score of 2.2. No single land cover type dominated the provision of supporting services and the values for this ES group were close to average.

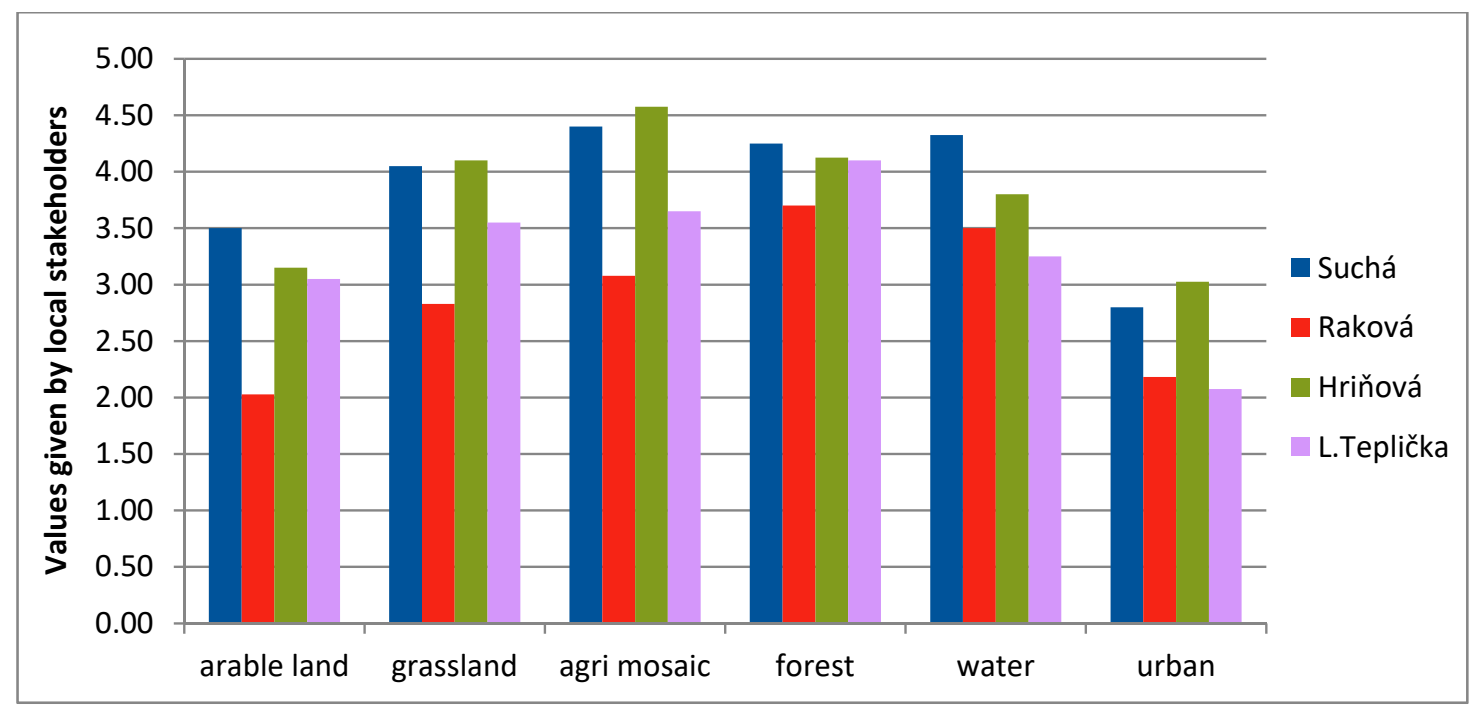

Figure 7. Local stakeholders' evaluation of the most important land cover types in providing services for human wellbeing.

We then compared responses obtained from key local stakeholders of the different study sites, as shown in Figure 7. Here, local stakeholders from intensively used landscapes evaluated most land cover types very positively for delivering services, and these scored a rating of 3.5-4. This however excluded the built-up areas. Wider rating ranges, however, were returned in mountain and sub-mountain areas. For example, Hriňová is a dispersed settlement area and has significant agricultural mosaic coverage, and stakeholders from this locality assessed this landscape form highly with a 4.6 rating. However, the responses for the Raková municipality are largely inexplicable. Raková stakeholders assigned low values to some 'close-to-nature' landscape elements. In particular, they gave only a 2.8 to 3 rating for agricultural mosaics and grasslands, and also their rating for arable land of approximately 2 was the lowest.

\section{Discussion}

Results from the case studies proved that overall supply of ecosystem services is lower in intensively used landscapes with their dominant arable land cover. In contrast, stakeholders from Suchá nad Parnou, which represents intensively used landscapes, strongly perceived the importance of ES benefits provided for human wellbeing. This inconsistency raises questions. Does this difference result from individual personal experience, and does the absence of valuable services in the landscape force local people to be more responsive to understand their importance? However, the stakeholders from Hriňová have very good access to the extensive agricultural land and forested and water areas [45], and they fully appreciate these values and the provision of related ecosystem services. Results from the remaining two case study areas are less expressive in comparison of current landscape capacity and public preferences for ecosystem services. Therefore, in a simplified conclusion, ecosystem service supply matches demand in Hriňová, and mismatch of these ES elements occurs in Suchá nad Parnou, i.e., when there is unequal quantity or quality at a specific scale or time [46,47].

Although understanding mismatches between ES supply and demand can be expedited by studying spatial relationships $[48,49]$, spatial flow is very complex and it generally extends far beyond the regional level, especially when mountain regions are included [50]. Spatial investigation is outside the scope of this article, and herein we concentrate on the interpretation of site-specific ES variables and their influence on perception of stakeholders. 
Our research results on ES supply correspond with ES supply-demand matrices investigated in other studies in general (see e.g., [17,41]). These substantially support the significance of natural capital, with the highest rankings assigned to forests. However, significant differences between experts' assessment in our study and the study of Burkhard et al. [17] are recorded; for example, on provision of recreation and aesthetic by discontinuous fabric and complex cultivation pattern or on provision of regulating services by transitional woodland shrub, i.e., much higher values were assigned by our responding experts. Although ES supply and demand (mis)match information is spatially explicit, similarities with our results are found in Quintas-Soriano et al.'s work [51]. These authors identified ES bundles which linked biophysical supply with social importance, and they also found mismatches between low ES supply and high public awareness, which we alluded to earlier in the Suchá nad Parnou municipality. Although the factors influencing 'land use change' were driven by rural abandonment in the above-quoted Spanish result and by Slovak agricultural intensification in the present study, the common recommendation is to engage the general public in environmental participatory planning. This would promote greater multi-functionality in the landscape [32]. This could also involve the following measures in Slovakia: establishing an interdisciplinary group of experts and stakeholders for landscape planning, improving open local government, and supporting the implementation of the Landscape-Ecological Plan at the municipal level.

Combined knowledge and experience at the local level then enables planning methods to be closely connected with the work of local action groups (LAGs), originated in the EU's LEADER initiative (an acronym in French-Liaison entre actions de développement de l'économie rurale-meaning "Links between actions for the development of the rural economy") [52]. Such groups have been established in many regions in Slovakia, with 57 LAGs recently registered, and with private and public specialists from various disciplines. However, their authority remains under-developed as they are tightly governed by a managing authority/priority axis, e.g., limited budget and thematic priorities, and complicated administration. An ideal precondition for appropriate operation of the ES concept at the landscape level is raising public awareness of nature's importance by locally interested parties like LAGs. Surprisingly, overall high-level of awareness was recorded in our study areas despite the ES concept being unknown there. This result may have different reasons [53]; for example, our respondents are key stakeholders and they have contact with landscape and ecosystems on a daily basis.

Although cultural services were restricted to aesthetic and recreational aspects in our research, their presence in most land cover types was highly ranked by the experts. This included those built-up areas with clear potential for providing cultural services, such as landscape-created sport and leisure facilities. Moreover, the benefits from these services are easy to access in most study areas. These services naturally appeal to local residents, nevertheless they were the worst ranked of all ES by both experts and stakeholders. However, they still exceeded medium values. In the literature, cultural services have the highest priority for stakeholders [50,54], or local identities assessed them as less valuable than other environmental service groups [55]. Moreover, the review of perceived ES benefits in European multi-functional landscapes found that "people's relationship with a landscape and the landscape characteristics related to accessibility" was the main determinant in cultural services assessments [56].

This prompts the following question. Do landscape cultural services have special meaning and therefore require a different approach in their assessment? Schaich et al.'s answer in their bibliographic research [57] was that cultural services as an ecosystem services concept are often omitted in current research. This omission could prove fatal in cultural landscape investigations because the results should reflect people's identities and values as it is embedded in the European Landscape Convention [26]. Most cultural services reflect an area's history, culture, and identity, and therefore 'natural capital' should not be the only consideration. For example, Fagerholm et al.'s results [58] give high ranking to social gathering sites clustered as cultural services. This interpretation may explain the above mentioned different public perceptions of these services. It also further supports the idea of 
landscape-oriented services and this 'landscape-oriented services' terminology is more appropriate in landscape research than services based strictly on ecosystems. This also emphasizes that people can find cultural value in their everyday surroundings, and therefore landscapes besides those with a high degree of natural capital are also valuable [59].

In addition, the ES most requested by the respondents is provisioning services. This is in stark contrast to the expected regard for cultural services, and it highlights that respondents consider the primary function of the landscape is to provide tangible outputs, and that provisioning services is the most comprehensible ES to achieve this aim. The remaining ecosystem services require increased awareness of nature and ecosystem values, and this is also proven in research results from the rural regions of other countries [55,60].

The group of provisioning services, however, created difficulty in its ability to explain overall landscape capacity. The average values for the provisioning ES category are not high because some distant single services are considered for the same land cover type, and their ultimate combination decreased the overall value. For example, arable land has high capacity to produce crops, but no capacity to produce timber or fresh water, while single services in other landscape categories are either inter-connected or at least they do not tend to cancel each other out. Although our research aimed to keep ecosystem services groupings simple for general public understanding, this finding limited providing more reliable results, and it is therefore more appropriate to avoid averaging individual provisioning services in research outputs.

Linking different scales and methods in landscape research is becoming increasingly important [61] and it helps provide scientific evidence closer to reality. Landscape assessment by the provision of ecosystem services for human wellbeing aims to complement the current complex view on landscape and its development. Landscape quality and its corresponding benefits should also be reflected in the demand for site-specific landscape planning. This demand forms only part of the complex overall landscape assessment, but it can be measured by investigating public preferences for ecosystem services at the landscape scale $[23,62,63]$. Precise participatory land use planning is then finalized by consensus between public opinion and institutional identities [64]. This approach presents a spatially larger scale in a collaborative process where the concept of ecosystem services is vitally important [65].

Participatory process and knowledge co-production can ensure sensitive assessment of future landscape transformation by integrative analysis of trade-offs and synergies between the different ES. Hölting et al. [32] consider these core elements in assessing landscape multi-functionality. However, the combination of transdisciplinary engagement and the inter-disciplinary constitution of participants in the process should be guaranteed in order to achieve sustainable multi-functional landscapes [66]. For example, the Slovak mountain forest areas are highly preferred for ecosystem services by the majority of the local stakeholders, but this preference should not be uncontrollably increased at the expense of small-scale agricultural areas [67]. Achieving this target requires an operational cross-sectoral panel at the national level, which should be facilitated by the Ministry of Environment and the Ministry of Agriculture and Regional Development of the Slovak Republic, and will then ensure regular assessment of strategic documents and regulatory instruments related to the ES concept [28]. Their agenda should also include national directives for applied integrated assessments and participatory procedures implemented in top-down procedures. For example, this approach would be necessary for the development of the Economic and Social Development Plan, which is the obligatory local strategic document required for Slovak municipal applications for national and EU funding.

The different expert responses, and especially those of the local stakeholders, proved that more in-depth personal interviews and social analysis are essential to confirm or disprove the above conclusions [19]. Most importantly, lack of knowledge causes great differences in assessing landscape benefits [20], and although Slovak stakeholders have limited ecosystem services knowledge, our survey proved that there is generally deep awareness of nature's benefits. The most evident difficulty here was assessing the role of supporting services, because uncertainty led to stakeholders assigning similar average values to the different land cover types. In addition to the weak implementation of participatory 
planning procedures and an insufficient multi-sectoral approach applied in Slovakia [28], the ecosystem service assessment in Slovak literature frequently relies on a single service or category without stakeholder engagement [68-70]. Moreover, participatory studies implemented at the landscape scale are rare, whether they are focused on specific service or land cover types [71-74], or they cover the overall landscape structure $[75,76]$.

\section{Conclusions}

Slovak ecosystem services are location-based. Different land uses, local habits, and other site-specific conditions affect the perceptions of the ES which become place-based [74,77]. The diverse services and their access are distinguishable [58], and although these are highly valued by local inhabitants [78-80], increasing societal demands on the environment limit priorities to the short term.

Our investigation differentiates local landscapes and their character and residents, and we strongly consider that public opinion must be heard and respected in the formulation of local decisions and plans. This will help ensure a multi-functional landscape and sustainable development, but it also requires the support of a well-developed national regulatory framework. The study also confirmed that significant and balanced stakeholder involvement is an important determinant in ES integrated trade-offs and synergies in a multi-functional landscape. Such a participatory approach will help counteract the low ranking of the ES supply recorded in our Suchá nad Parnou analysis. The significant mismatches noted in ecosystem service supply and demand can then be ameliorated by appropriately integrated local policy decisions. Moreover, we fully concur with de Groot et al. [81] that landscape conversions which limit the provision of multiple services can provide only short-term benefits to a few involved entities at the expense of the long-term wellbeing of many.

In conclusion, further research examples are now required to persuade decision-makers and planners to integrate landscape values and ecosystem services. While this paper determines the general trends in perceiving and delivering ecosystem services throughout Slovakia, that additional research is essential to transform ecosystem service approaches into practical landscape applications.

Author Contributions: Conceptualization, P.B., Z.I. and P.M.; methodology, P.B., Z.I. and P.M.; software, P.M. and M.B.; formal analysis, P.B., Z.I. and P.M.; investigation, M.M., Z.I. and M.B.; data curation, P.M. and P.B.; writing-original draft preparation, P.B.; writing—review and editing, P.B., P.M., Z.I. and M.M.; visualization, P.M. and M.B.; supervision, Z.I. and M.M. All authors have read and agreed to the published version of the manuscript.

Funding: This research was funded by the Slovak Research and Development Agency, project APVV-17-0377 "Assessment of recent changes and trends in the agricultural landscape of Slovakia" and by the Integrated Infrastructure Operational Programme funded by the ERDF, project ITMS2014+313011W580, Scientific support of climate change adaptation in agriculture and mitigation of soil degradation.

Conflicts of Interest: The authors declare no conflict of interest.

\section{References}

1. Forman, R.T.T.; Godron, M. Landscape Ecology; John Wiley \& Sons, Inc.: New York, NY, USA, 1986; p. 619.

2. Millennium Ecosystem Assessment. Millennium Ecosystem Assessment Ecosystems and Human Well-Being: A Framework for Assessment; Island Press: Washington, DC, USA, 2003; p. 245.

3. Paracchini, M.L.; Capitani, C. Implementation of a EU wide indicators for the rural-agrarian landscape. JRC Sci. Tech. Rep. 2011, 91. [CrossRef]

4. Bastian, O.; Röder, M. Assessment of landscape change by land evaluation of past and present situation. Landsc. Urban. Plan. 1998, 41, 171-182. [CrossRef]

5. Willemen, L.; Verburg, P.H.; Hein, L.; van Mensvoort, M.E.F. Spatial characterization of landscape functions. Landsc. Urban. Plan. 2008, 88, 34-43. [CrossRef]

6. Botequilha-Leitão, A.; Ahern, J. Applying Landscape Ecological Concepts and Metrics in Sustainable Landscape Planning. Landsc. Urban. Plan. 2002, 59, 65-93. [CrossRef]

7. Walz, U. Landscape structure, landscape metrics and biodiversity. Living Rev. Landsc. Res. 2011, 5, 1-35. [CrossRef] 
8. Cassatella, C.; Peano, A. Landscape Indicators: Assessing and Monitoring Landscape Quality; Springer: Dordrecht, The Netherlands, 2011; p. 222.

9. Enengel, B.; Penker, M.; Muhar, A.; Williams, R. Benefits, efforts and risks of participants in landscape co-management: An analytical framework and results from two case studies in Austria. J. Environ. Manag. 2011, 92, 1256-1267. [CrossRef]

10. McCall, M.K.; Dunn, C.E. Geo-information tools for participatory spatial planning: Fulfilling the criteria for 'good' governance? Geoforum 2012, 43, 81-94. [CrossRef]

11. Liu, J.; Opdam, P.F.M. Valuing ecosystem services in community-based landscape planning: Introducing a wellbeing-based approach. Landsc. Ecol. 2014, 29, 1347-1360. [CrossRef]

12. The Common International Classification of Ecosystem Services (CICES). CICES Version 5.1. Available online: www.cices.eu (accessed on 5 June 2020).

13. Mapping and Assessment of Ecosystems and their Services (MAES). Available online: https://biodiversity. europa.eu/maes (accessed on 5 June 2020).

14. Iverson, L.; Echeverria, C.; Nahuelhual, L.; Luque, S. Ecosystem services in changing landscapes: An introduction. Landsc. Ecol. 2014, 29, 181-186. [CrossRef]

15. Ayumi, Y.; Chanhda, H. Ecosystem Service Values and Land Use Change in Trans-Boundary National Biodiversity Conservation Areas (NBCA): A Case study of Phou Dean Din NBCA, Lao PDR. In Proceedings of the 8th International Conference of the European Society for Ecological Economics, Ljubljana, Slovenia, 29 June-2 July 2009.

16. Burkhard, B.; Kroll, F.; Muller, F.; Windhorst, W. Landscapes' Capacities to Provide Ecosystem Services-A Concept for Land-Cover Based Assessments. Landsc. Online 2009, 15, 1-22. [CrossRef]

17. Burkhard, B.; Kroll, F.; Nedkov, S.; Müller, F. Mapping ecosystem service supply, demand and budgets. Ecol. Indic. 2012, 21, 17-29. [CrossRef]

18. Buijs, A.E.; Pedroli, B.; Luginbühl, Y. From hiking through farmland to farming in a leisure landscape: Changing social perceptions of the European landscape. Landsc. Ecol. 2006, 21, 375-389. [CrossRef]

19. Martín-López, B.; Iniesta-Arandia, I.; García-Llorente, M.; Palomo, I.; Casado-arzuaga, I.; Amo, D.G.D.; Gómez-Baggethun, E.; Oteros-Rozas, E.; Palacios-Agundez, I.; Willaarts, B.; et al. Uncovering ecosystem service bundles through social preferences. PLoS ONE 2012, 7, e38970. [CrossRef] [PubMed]

20. Kopperoinen, L.; Itkonen, P.; Niemelä, J. Using expert knowledge in combining green infrastructure and ecosystem services in land use planning: An insight into a new place-based methodology. Landsc. Ecol. 2014, 29, 1361-1375. [CrossRef]

21. Paracchini, M.L.; Zulian, G.; Kopperoinen, L.; Maes, J.; Schägner, J.P.; Termansen, M.; Zandersen, M.; Perez-Soba, M.; Scholefield, P.A.; Bidoglio, G. Mapping cultural ecosystem services: A framework to assess the potential for outdoor recreation across the EU. Ecol. Indic. 2014, 45, 371-385. [CrossRef]

22. Kroll, F.; Müller, F.; Haase, D.; Fohrer, N. Rural-urban gradient analysis of ecosystem services supply and demand dynamics. Land Use Policy 2012, 29, 521-535. [CrossRef]

23. Garcia-Nieto, A.P.; Garcia-Llorente, M.; Iniesta-Arandia, I.; Martín-López, B. Mapping forest ecosystem services: From providing units to beneficiaries. Ecosyst. Serv. 2013, 4, 126-138. [CrossRef]

24. Termorshuizen, J.W.; Opdam, P.F.M. Landscape services as a bridge between landscape ecology and sustainable development. Landsc. Ecol. 2009, 24, 1037-1052. [CrossRef]

25. Bastian, O.; Haase, D.; Grunewald, K. Ecosystem properties, potentials and services-The EPPS conceptual framework and an urban application example. Ecol. Indic. 2012, 21, 7-16. [CrossRef]

26. Council of Europe. European Landscape Convention. Available online: https://rm.coe.int/ CoERMPublicCommonSearchServices/DisplayDCTMContent?documentId=09000016802f80c6 (accessed on 5 June 2020).

27. Bouwma, I.; Schleyer, C.; Primmer, E.; Winkler, K.J.; Berry, P.; Young, J.; Carmen, E.; Špulerová, J.; Bezák, P.; Vadineanu, A. Adoption of the ecosystem services concept in EU policies. Ecosyst. Serv. 2018, 29, $213-222$. [CrossRef]

28. Bezák, P.; Mederly, P.; Izakovičová, Z.; Špulerová, J.; Schleyer, C. Divergence and conflicts in landscape planning across spatial scales in Slovakia: An opportunity for an ecosystem services-based approach? Int. J. Biodivers. Sci. Ecosyst. Serv. Manag. 2017, 13, 119-135. [CrossRef]

29. Brown, C.; Grant, M. Biodiversity and Human Health: What Role for Nature in Healthy Urban Planning? Built Environ. 2005, 31, 326-338. [CrossRef] 
30. Opdam, P. Implementing human health as a landscape service in collaborative landscape approaches. Landsc. Urban. Plan. 2020, 199, 103819. [CrossRef]

31. Stürck, J.; Verburg, P.H. Multifunctionality at what scale? A landscape multifunctionality assessment for the European Union under conditions of land use change. Landsc. Ecol. 2017, 32, 481-500. [CrossRef]

32. Hölting, L.; Beckmann, M.; Volk, M.; Cord, A.F. Multifunctionality assessments-More than assessing mutiple ecosystem functions and services? A quantitative literature review. Ecol. Ind. 2019, 103, 226-235. [CrossRef]

33. Operationalisation of Natural Capital and Ecosystem Services (OpenNESS). Available online: http://www. openness-project.eu/ (accessed on 5 June 2020).

34. Feranec, J.; Nováček, J. The CORINE land cover database of Slovakia and its changes in the period 2000-2006. Morav. Geogr. Lett. 2009, 17, 2-9.

35. Ot'ahel, J.; Feranec, J.; Kopecká, J.; Falt’an, V. Modifikácia metódy CORINE Land Cover a legenda pre identifikáciu a zaznamenávanie tried krajinnej pokrývky v mierke 1:10,000 na báze príkladových štúdií z územia Slovenska. Geogr. Čas. 2017, 69, 189-224.

36. Erb, K.H.; Harbel, H.; Jepsen, M.R.; Kuemmerle, T.; Lindner, M.; Müller, D.; Verburg, P.H.; Reenberg, A. A conceptual framework for analysing and measuring land-use intensity. Curr. Opin. Env. Sust. 2013, 5, 464-470. [CrossRef]

37. Estel, S.; Kuemmerle, T.; Levers, C.; Baumann, M.; Hostert, P. Mapping cropland-use intensity across Europe using MODIS NDVI time series. Envoron. Res. Lett. 2016, 11, 024015. [CrossRef]

38. Rega, C.; Short, C.; Pérez-Soba, M.; Paracchini, M.L. A classification of European agricultural land using an energy-based intensity indicator and detailed crop description. Landsc. Urban. Plan. 2020, 198, 103793. [CrossRef]

39. Vihervaara, P.; Kumpula, T.; Tanskanen, A.; Burkhard, B. Ecosystem services-A tool for sustainable management of human-environment systems. Case study Finnish Forest Lapland. Ecol. Complex. 2010, 7, 410-420. [CrossRef]

40. Campagne, C.S.; Roche, P.; Gosselin, F.; Tschanz, L. Expert-based ecosystem services capacity matrices: Dealing with scoring variability. Ecol. Ind. 2017, 79, 63-72. [CrossRef]

41. Sun, X.; Tang, H.; Yang, P.; Hu, G.; Liu, Z.; Wu, J. Spatiotemporal patterns and drivers of ecosystem service supply and demand across the conterminous United States: A multiscale analysis. Sci. Total Environ. 2020, 703, 135005. [CrossRef] [PubMed]

42. Roche, P.; Campagne, S. Are expert-based ecosystem services scores related to biophysical quantitative estimates? Ecol Indic. 2019, 106, 1-10. [CrossRef]

43. Geodesy, Cartography and Cadastre Authority of the Slovak Republic, GIS portal. Available online: https://zbgis.skgeodesy.sk (accessed on 5 June 2020).

44. National Forest Centre (NCL), NCL GIS Portal. Available online: http://gis.nlcsk.org/lgis/ (accessed on 5 June 2020).

45. Mojses, M.; Petrovič, F. Land use changes of historical structures in the agricultural landscape at the local level-Hriňová case study. Ekol. Bratisl. 2013, 32, 1-12. [CrossRef]

46. Geijzendorffer, I.R.; Martín-López, B.; Roche, P.K. Improving the identification of mismatches in ecosystem servicesassessments. Ecol. Indic. 2015, 52, 320-331. [CrossRef]

47. Yang, Q.; Dobbie, M.F. Importance-satisfaction analysis of cultural ecosystem services of multifunctional landscapes designed for stormwater management. Landsc. Archit. Front. 2019, 7, 52-67. [CrossRef]

48. Burkhard, B.; Kandziora, M.; Hou, Y.; Müller, F. Ecosystem Service Potentials, Flows and Demands-Concepts for Spatial Localisation, Indication and Quantification. Landsc. Online 2014, 34, 1-32. [CrossRef]

49. Syrbe, R.U.; Grunewald, K. Ecosystem service supply and demand-the challenge to balance spatial mismatches. Int. J. Biodivers. Sci. Ecosyst. Serv. Manag. 2017, 13, 148-161. [CrossRef]

50. Schirpke, U.; Tappeiner, U.; Tasser, E. A transnational perspective of global and regional ecosystem service flows from and to mountain regions. Sci. Rep. 2019, 9, 6678. [CrossRef]

51. Quintas-Soriano, C.; García, M.; Norström, A.; Meacham, M.; Castro, A.J. Integrating supply and demand in ecosystem service bundles characterization across Mediterranean transformed landscapes. Landsc. Ecol. 2019, 34, 1619-1633. [CrossRef]

52. Melichová, K.; Varecha, L. Endogenous Political, Institutional, Cultural, and Geographic Determinants of Intermunicipal Cooperation-Evidence from Slovakia. Sustainability 2020, 12, 709. [CrossRef] 
53. Tasser, E.; Schripke, U.; Zoderer, B.M.; Tappeiner, U. Towards an integrative assessment of land-use type values from the perspective of ecosystem services. Ecosyst. Serv. 2020, 42, 101082. [CrossRef]

54. Van der Biest, K.; Meire, P.; Schellekens, T.; D’hondt, B.; Bonte, D.; Vanagt, T.; Ysebaert, T. Aligning biodiversity conservation and ecosystem services in spatial planning: Focus on ecosystem processes. Sci. Total Environ. 2020, 712, 136350. [CrossRef] [PubMed]

55. Włodarczyk-Marciniak, R.; Frankiewicz, P.; Krauze, K. Socio-cultural valuation of Polish agricultural landscape components by farmers and its consequences. J. Rural Stud. 2020, 74, 190-200. [CrossRef]

56. Fagerholm, N.; Torralba, M.; Moreno, G.; Girardello, M.; Herzog, F.; Aviron, S.; Burgess, P.; Crous-Duran, J.; Ferreiro-Domínguez, N.; Graves, A.; et al. Cross-site analysis of perceived ecosystem service benefits in multifunctional landscapes. Glob. Environ. Chang. 2019, 56, 134-147. [CrossRef]

57. Schaich, H.; Bieling, C.; Plieninger, T. Linking Ecosystem Services with Cultural Landscape Research. GAIA Ecol. Perspect. Sci. Soc. 2010, 19, 269-277. [CrossRef]

58. Fagerholm, N.; Eilola, S.; Kisanga, D.; Arki, V.; Käyhkö, N. Place-based landscape services and potential of participatory spatial planning in multifunctional rural landscapes in Southern highlands, Tanzania. Landsc. Ecol. 2019, 34, 1769-1787. [CrossRef]

59. Plieninger, T.; Dijks, S.; Oteros-Rozas, E.; Bieling, C. Assessing, mapping, and quantifying cultural ecosystem services at community level. Land Use Policy 2013, 33, 118-129. [CrossRef]

60. Tauro, A.; Gómez-Baggethun, E.; García-Frapolli, E.; Lazos Chavero, E.; Balvanera, P. Unraveling heterogeneity in the importance of ecosystem services: Individual views of smallholders. Ecol. Soc. 2018, 23, 11. [CrossRef]

61. Pedroli, B.; Pinto-Correia, T.; Cornish, P. Landscape-What's in it? Trends in European Landscape Science and Priority Themes for Concerted Research. Landsc. Ecol. 2006, 21, 421-430. [CrossRef]

62. Martín-López, B.; Gómez-Baggethun, E.; García-Llorente, M.; Montes, C. Trade-offs across value-domains in ecosystem services assessment. Ecol. Indic. 2014, 37, 220-228. [CrossRef]

63. Keller, R.; Clivaz, M.; Reynard, E.; Backhaus, N. Increasing Landscape Appreciation through the Landscape Services Approach. A Case Study from Switzerland. Sustainability 2019, 11, 5826. [CrossRef]

64. Fürst, C.; Opdam, P.; Inostroza, L.; Luque, S. Evaluating the role of ecosystem services in participatory land use planning: Proposing a balanced score card. Landsc. Ecol 2014, 29, 1435-1446. [CrossRef]

65. Westerink, J.; Opdam, P.; Van Rooij, S.; Steingröver, E. Landscape services as boundary concept in landscape governance: Building social capital in collaboration and adapting the landscape. Land Use Policy 2017, 60, 408-418. [CrossRef]

66. O'Farrell, P.J.; Anderson, P.M. Sustainable multifunctional landscapes: A review to implementation. Curr. Opin. Environ. Sust. 2010, 2, 59-65. [CrossRef]

67. Pazúr, R.; Bolliger, J. Land changes in Slovakia: Past processes and future directions. Appl. Geogr. 2017, 85, 163-175. [CrossRef]

68. Kopecká, M.; Szatmári, D.; Rosina, K. Analysis of Urban Green Spaces Based on Sentinel-2A: Case Studies from Slovakia. Land 2017, 6, 25. [CrossRef]

69. Bujnovský, R. Estimation of benefits from the actual use of inland water ecosystem services in the Slovak Republic. Ekol. Bratisl. 2018, 37, 201-218. [CrossRef]

70. Makovníková, J.; Pálka, B.; Širáň, M.; Kizekova, M.; Kanianska, R. The potential of regulating ecosystem service-Filtering potential for inorganic pollutants—Supplied by soils of Slovakia. Hung. Geogr. Bull. 2019, 68, 177-185. [CrossRef]

71. Baránková, Z.; Dobrovodská, M.; Štefunková, D.; Babicová, D.; Moyzeová, M.; Petrovič, F. Participation of local people on identifying the landscape values and future development in historical agricultural landscapes. Ekol. Bratisl. 2011, 30, 216-228. [CrossRef]

72. Považan, R.; Getzner, M.; Švajda, J. On the valuation of ecosystem services in Muránska Planina National Park (Slovakia). Eco. Mont. 2015, 7, 61-69. [CrossRef]

73. Sarvašová, Z.; Dobšinská, Z. Provision of ecosystem services in mountain forests-Case study of experts' and stakeholders' perceptions from Slovakia. J. Forest. Sci. 2016, 62, 380-387. [CrossRef]

74. Špulerová, J.; Perovič, F.; Mederly, P.; Mojses, M.; Izakovičová, Z. Contribution of traditional farming to ecosystem services provision: Case studies from Slovakia. Land 2018, 7, 1-24. [CrossRef]

75. Bezák, P.; Bezáková, M. Landscape capacity for ecosystem services provision based on expert knowledge and public perception (case study from the north-west Slovakia). Ekol. Bratisl. 2014, 33, 344-353. [CrossRef] 
76. Moyzeová, M. Inclusion of the Public in the Natural Capital, Ecosystem Services and Green Infrastructure Assessments (Results of Structured Interviews with Stakeholders of Commune Liptovská Teplička). Ekol. Bratisl. 2018, 37, 42-56. [CrossRef]

77. Dobrovodská, M.; Kanka, R.; David, S.; David, S.; Kollár, J.; Špulerová, J.; Štefunková, D.; Mojses, M.; Petrovič, F.; Krištín, A.; et al. Assessment of the biocultural value of traditional agricultural landscape on a plot-by-plot level: Case studies from Slovakia. Biodivers. Conserv. 2019, 28, 2615-2645. [CrossRef]

78. Lewan, L.; Söderqvist, T. Knowledge and recognition of ecosystem services among the general public in a drainage basin in Scania, Southern Sweden. Ecol. Econ. 2002, 42, 459-467. [CrossRef]

79. Agbenyega, O.; Burgess, P.J.; Cook, M.; Morris, J. Application of an ecosystem function framework to perceptions of community woodlands. Land Use Policy 2009, 26, 551-557. [CrossRef]

80. Hartter, J. Resource Use and Ecosystem Services in a Forest Park Landscape. Soc. Natur. Resour. 2010, 23, 207-223. [CrossRef]

81. De Groot, R.S.; Alkemade, R.L.; Braat, L.; Hein, L.; Willemen, L. Challenges in integrating the concept of ecosystem services and values in landscape planning, management and decision making. Ecol. Complex. 2010, 7, 260-272. [CrossRef]

(C) 2020 by the authors. Licensee MDPI, Basel, Switzerland. This article is an open access article distributed under the terms and conditions of the Creative Commons Attribution (CC BY) license (http://creativecommons.org/licenses/by/4.0/). 